\title{
脳動脈瘤手術における術中皮質血流測定の 有用性について
}

\author{
長尾 省吾, 植田 清隆, 吉岡 純二, 三野 章 呉 \\ 藤原敬, 土田高宏，大本堯史
}

\section{Intraoperative Monitoring of Cortical Blood Flow During Aneurysm Surgery}

Seigo Nagao, M.D., Kiyotaka Ueta, M.D., Junji Yoshioka, M.D., Syogo Mino, M.D.,

Takashi Fujiwara, M.D., Takahiro Tsuchida, M.D., and Takashi Онмото, M.D.

Department of Neurological Surgery, Kagawa Medical School, Kagawa, Japan

Summary : During aneurysm surgery, regional cortical blood flow (CoBF) was continuously monitored in six patients with a thermal diffusion flow probe in an attempt to assess the effects of temporary major artery occlusion on flow.

The equipment and methods employed are presented in this paper. The CoBF was stable between 50 to $70 \mathrm{ml} / 100 \mathrm{~g} / \mathrm{min}$. Changes in flow due to vascular occlusion were readily apparent.

The reduction in flow was milder in common and internal carotid occlusion than in the obliteration of the middle $\left(\mathrm{M}_{1}\right)$ and anterior $\left(\mathrm{A}_{1}\right)$ cerebral artery.

The occlusion time varied from 0.5 to 14 minutes and $\mathrm{CoBF}$ decreased to 15 to $50 \mathrm{~m} / / 100 \mathrm{~g} / \mathrm{mim}$.

Five patients showed no postoperative deficits. Their $\mathrm{CoBF}$ and occlusion time were as follows: $15 \mathrm{~m} / / 100 \mathrm{~g} / \mathrm{min}$ for one minute, $25 \mathrm{~m} / / 100 \mathrm{~g} / \mathrm{min}$ for eight minutes and $50 \mathrm{ml} / 100 \mathrm{~g} / \mathrm{min}$ for $14 \mathrm{mi}$ nutes.

One patient revealed bilateral basal ganglia infarction after occlusion of the dominant left $A_{1}$ seg. ment for six to eight minutes, which was not detected by CoBF monitoring.

Attention should be paid to the blood flow in the deep structures when a temporary clip is applied at the site proximal to perforating branches.

Direct measurement of $\mathrm{CoBF}$ may be of value in estimating the length of time that temporary clipping of a major vessel can be tolerated.

\section{はじめに}

脳動脈瘤や脳動静脈奇形 (AVM) をはじめとする種々の 脳血管障害の手術に際して, 皮質脳血流 $(\mathrm{CoBF})^{1) \sim 4)}$ や誘 発反応 ${ }^{5)}$ を測定し, 術中の異常な血流や神経機能の変化を モニタリングする試みがなされている.AVMの症例では, ドプラー流速計によって流入流出動静脈や脳深部に存在す るAVMの同定が行われたり ${ }^{6)}$, STA-MCA 吻合術やモ
Key words :

- aneurysm surgery

- intraoperative monitoring

- cortical blood flow

- temporary occlusion

- cerebral ischemia
ヤモヤ病における血管吻合術では，術中 CoBF の測定に よって手術効果や血流動態が検討された報告もある ${ }^{2) 3)}$. われわれは術中に血流遮断が予想される脳動脈瘤や AVM の症例に対して，手術をより安全かつ確実に行うた めに術中 CoBF を測定しているが, 本稿では脳動脈瘤症 例につき，親動脈一時血流遮断の $\mathrm{CoBF}$ および術後神経 機能に及ぼす影響を中心に述べる。 
Table 1 Symmary of patients with intraoperative monitoring of cortical blood flow during aneurysm surgery

\begin{tabular}{|c|c|c|c|c|c|c|c|c|c|}
\hline Case & $\begin{array}{l}\text { Age }(y r) \\
\text { Sex }\end{array}$ & $\begin{array}{c}\text { Site of } \\
\text { aneurysm }\end{array}$ & $\begin{array}{l}\text { Preope } \\
\text { grade }\end{array}$ & $\begin{array}{l}\text { Occluded } \\
\text { artery }\end{array}$ & $\begin{array}{l}\text { Occlusion } \\
\text { time (min) }\end{array}$ & Mannitol & $\begin{array}{c}\text { Decrease of CoBF } \\
\text { by occlusion } \\
(\mathrm{m} l / 100 \mathrm{~g} / \mathrm{min})\end{array}$ & $\begin{array}{c}\text { Neurological } \\
\text { deficit } \\
\text { due to } \\
\text { temporary } \\
\text { occlusion }\end{array}$ & $\begin{array}{l}\text { Clinical } \\
\text { outcome }\end{array}$ \\
\hline 1 & $50 \mathrm{M}$ & $\begin{array}{l}\text { Lt. IC- } \\
\text { ophthalmic }\end{array}$ & I & Rt. $\mathrm{CC}+\mathrm{EC}$ & 14 & - & $60 \rightarrow 50$ & - & excellent \\
\hline 2 & $70 \mathrm{~F}$ & Rt. IC-PC & IV & Rt. CC & 4.5 & + & $60 \rightarrow 35$ & - & excellent \\
\hline 3 & $59 \mathrm{M}$ & Rt. MCA & III & Rt. $M_{1}$ & $9.5,3$ & - & $\begin{array}{l}55 \longrightarrow 30 \\
55 \longrightarrow 35\end{array}$ & - & excellent \\
\hline 4 & $51 \mathrm{M}$ & Lt. $A_{1}$ & IV & Lt. CC, IC, $\mathrm{M}_{1}$ & $3,3,1$ & + & $\begin{array}{l}60 \rightarrow 40(\mathrm{CC}) \\
60 \rightarrow 45(\mathrm{IC}) \\
60 \rightarrow 15\left(\mathrm{M}_{1}\right)\end{array}$ & - & died \\
\hline 5 & $73 \mathrm{~F}$ & $A \operatorname{com} A$ & III & Lt. CC, $\mathrm{A}_{1}$ & $0.5,6.5,8$ & + & $\begin{array}{l}60 \rightarrow 40(\mathrm{CC}) \\
60 \rightarrow 30\left(\mathrm{~A}_{1}\right)\end{array}$ & + & poor \\
\hline 6 & $54 \mathrm{~F}$ & Rt. MCA & II & Rt. $M_{1}$ & 8 & - & $55 \rightarrow 25$ & - & excellent \\
\hline
\end{tabular}

CC: common carotid artery, EC: external carotid artery, IC: internal carotid artery, MCA: middle cerebral artery, A com A: anterior communicating artery, $\mathrm{M}_{1}: \mathrm{M}_{1}$ segment of middle cerebral artery, $\mathrm{A}_{1}: \mathrm{A}_{1}$ segment of anterior cerebral artery, CoBF: cortical blood flow.

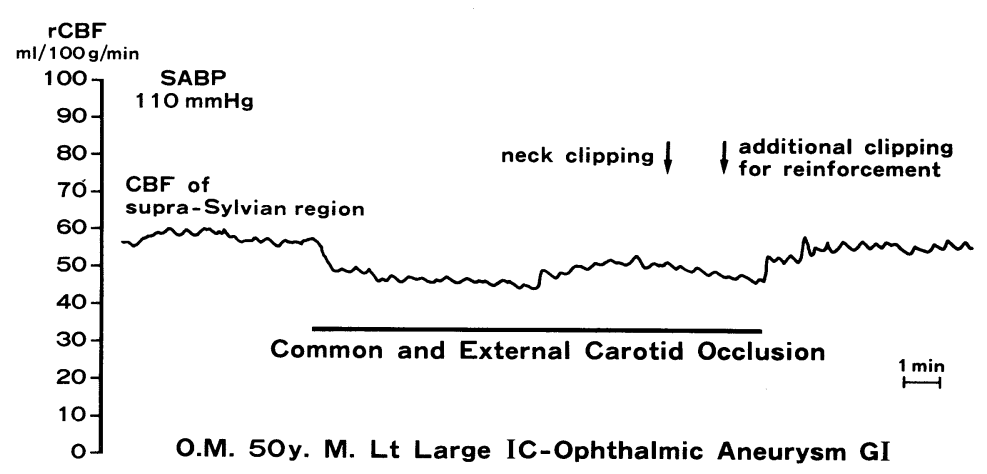

Fig. 1 Case 1. CoBF tracing during common and external carotid occlusion, demonstrating adequate collateral circulation.

\section{対象および方法}

術中 CoBF 測定下に血流遮断がなされた脳動脈瘤は 9 例であるが，そのうち 6 例を対象とした(Table 1). 血流 遮断は頸動脈圧迫あるいは杉田のクリップを用い, 瘤の位 置に応じて, 総頸動脈, 総頸動脈十外頸動脈, 頭蓋内内頸 動脈, 中大脳動脈 $\mathrm{M}_{1}$ (多くは末梢部 $\mathrm{M}_{1}$ ), 一側あるいは 両側 $A_{1}$ で行った.

$\mathrm{CoBF}$ 測定はユニーク・メディカル社製の制御差温式組 織血流計 (UMW-101-S4)を用いた. この脳血流計の原理 は, ヒートクリアランス法であるが, 死脳で 0 レベルを設 定し，水素クリアランス法で得られた生脳 CoBF の実測 值をデジタル表示值に scale adjustして, CoBF の絶対值 が連続的に測定できるように改良されており, 安定した術 中記録が可能である.

実際の測定にあたっては, pterional approachによって 露出されたシルビウス裂上部の前頭葉脳表に密着するよう
に直径 $13 \mathrm{~mm}$ のプレート電極をおき，さらに湿綿シートで 被い, 電極の移動や脳表乾燥のないように圧着した. 電極 の位置は遮断される動脈によって適宜その灌流領域とした. 血流測定範囲は電極の接触面下約 $2 \mathrm{~mm}$ とされている.

最初に症例を呈示する.

〈症例 1〉50歳, 男性.

Lt. IC-ophthalmic aneurysm. 収縮期血圧約 $110 \mathrm{mmHg}$ として, あらかじめ露出していた総頸および外頸動脈を閉 塞したところ, 前頭葉 $\mathrm{CoBF}$ は60より約 $50 \mathrm{~m} l / 100 \mathrm{~g} / \mathrm{min}$ と $20 \%$ 以下の減少にとどまった (Fig. 1).ネックの剝離, クリッピングに際し, 約14分間の血流遮断を要したが, 術 後, 遮断による神経脱落症状は認められなかった。

〈症例 2〉70歳, 女性.

Rt. IC-PC aneurysm. Grade IV, day 3 で手術. 動脈瘤を 剥離後, クリッピングに際して右総頸動脈を圧迫したとこ 


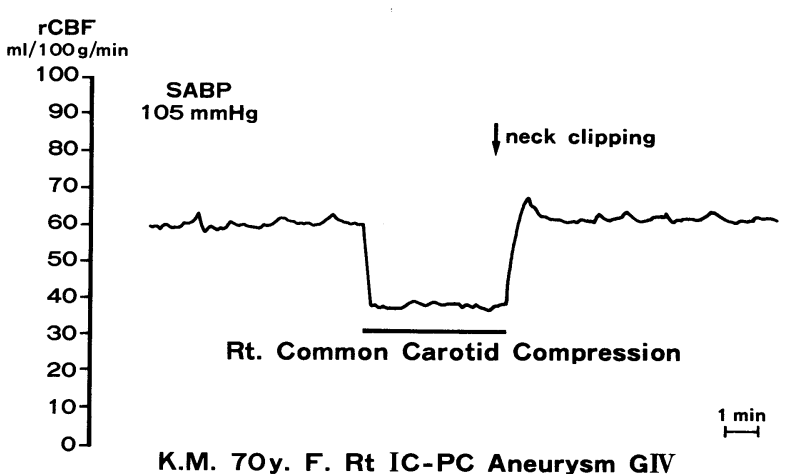

Fig. 2 Case 2. Effect of compression of common carotid artery on $\mathrm{CoBF}$.

ろ， CoBF は60より約 $35 \mathrm{~m} l / 100 \mathrm{~g} / \mathrm{min}$ と約 $40 \%$ 低下したた め, 圧迫遮断時間を 4 分 30 秒と短縮してクリッピングを終 えた (Fig. 2)．術後血流遮断によると思われる脱落症状は 出現しなかった，術前 G IVであったが，発症以前と同状 態まで回復し，元気に退院した。

〈症例 3〉59歳, 男性.

Rt. MCA aneurysm. Grade III, day 10で手術. 術中動脈 瘤破裂のため $\mathrm{M}_{1}$ 末梢部にて血流遮断 ( 9 分 30 秒)，クリッ ピングを行った。この際 $\mathrm{CoBF}$ は55より $30 \mathrm{~m} l / 100 \mathrm{~g} / \mathrm{min}$ と約 $45 \%$ 低下した。 そこで一時遮断を約 3 分間と短縮して クリップをかけ直した．術後なんら神経脱落症状なく退院 した(Fig. 3).

〈症例 4〉51歳, 男性.

Lt. $A_{1}$ aneurysm. Grade IV, day2 で手術. 総頸あるいは 内頸動脈の一時血流遮断では, CoBF は60より 40,
$45 \mathrm{~m} l / 100 \mathrm{~g} / \mathrm{min}$ と減じたが, $\mathrm{M}_{1} 1$ 分間遮断では $15 \mathrm{~m} l / 100 \mathrm{~g} / \mathrm{min}$ と著明に低下した (Fig. 4). 術後遮断によ ると思われる新たな神経脱落症状は認められなかったが, 脳血管攣縮による両半球脳梗塞で死亡した.

〈症例 5〉73歳, 女性.

A Com aneurysm. Grade III, day 3 で手術. CoBF は総 頸動脈の圧迫で 60 より $40 \mathrm{~m} / / 100 \mathrm{~g} / \mathrm{min}$ と減少した。本例 では右 $\mathrm{A}_{1}$ は hypoplasia. 穿通枝の剝離および確保, クリ ッピングのため左 $\mathrm{A}_{1}$ の一時遮断を $6.5,8$ 分間の 2 回行っ たが，この際 $\mathrm{CoBF}$ は60より $30 \mathrm{ml} / 100 \mathrm{~g} / \mathrm{min}$ と $50 \%$ 低下 した．術後意識レベルは半昏睡と悪化して，CT で両側大 脳基底核部に低吸収域の出現を認め, 恐らく一時血流遮断 による穿通枝領域の虚血がその原因であろうと推定された. 患者は脳血管攣縮による広範囲な脳梗塞も合併し, 半昏睡 状態で臥床している.

\section{症例 の総括}

$\mathrm{CoBF}$ は正常では50〜 70m $/ / 100 \mathrm{~g} / \mathrm{min}$ の範囲で安定して いたが，血流遮断後は急激に低下し，遮断中はほぼ一定の 血流を保ち，遮断解除後は一過性に高值をとり，数分後に 遮断前の值に復する傾向がみられた。

総頸動脈あるいは内頸動脈の遮断後には, CoBF は前値 の $60 \sim 85 \%(35 \sim 40 \mathrm{~m} l / 100 \mathrm{~g} / \mathrm{min})$ と比較的良好に保たれて いたが， $\mathrm{M}_{1}$ るいは $\mathrm{A}_{1}$ の遮断では，前值の25〜65\% (15 $\sim 35 \mathrm{~m} / / 100 \mathrm{~g} / \mathrm{min}$ ) とより著明に低下した.

$\mathrm{CoBF}$ が $30 \mathrm{~m} l / 100 \mathrm{~g} / \mathrm{min}$ 以下に低下した例の遮断時間は 1 分から 9 分 30 秒 ( 4 回)であるが，そのうち 1 例 (8 分遮 断)に穿通枝領域の虚血が発現した.

$\mathrm{CoBF}$ が $30 \mathrm{~m} / / 100 \mathrm{~g} / \mathrm{min}$ 以上に保たれていた例の最高遮

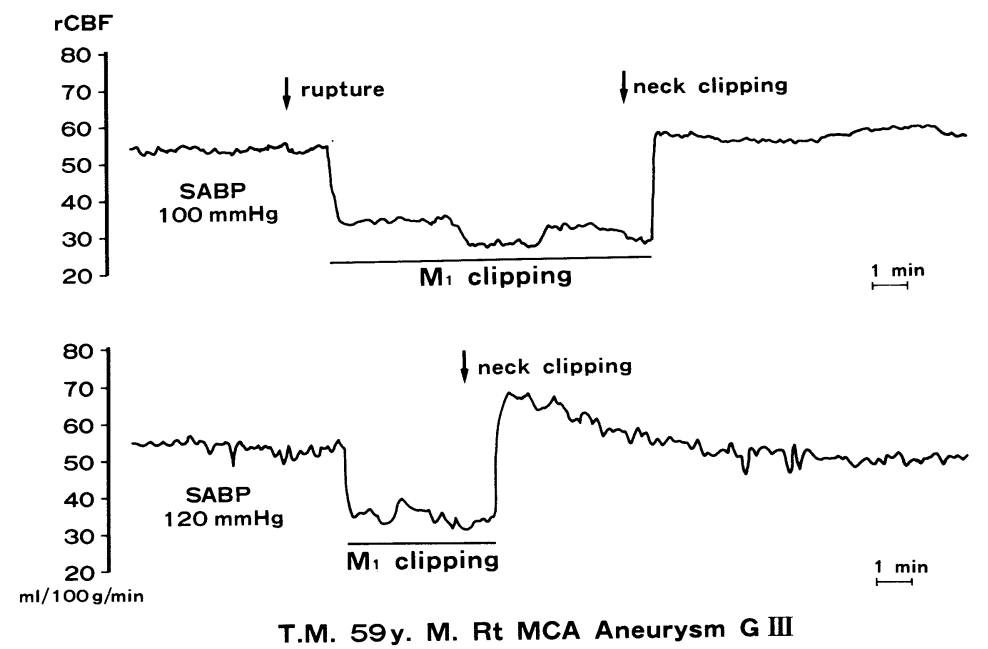

Fig. 3 Case 3. CoBF recording during occlusion of $\mathrm{M}_{1}$ portion of middle cerebral artery. 

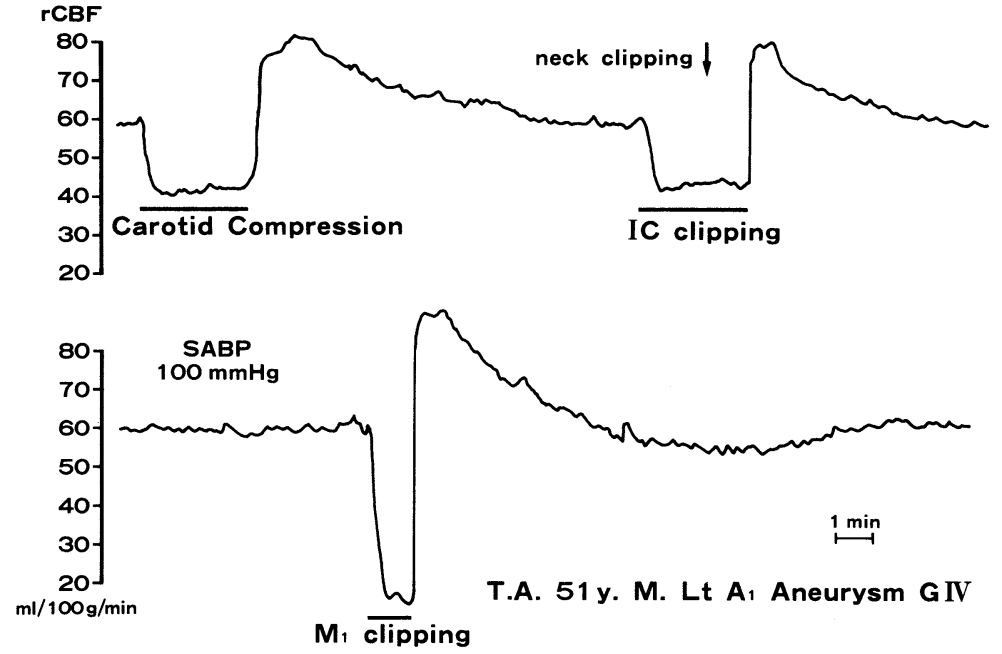

Fig. 4 Case 4. Monitoring of $\mathrm{CoBF}$ during carotid compression, clipping of intracranial internal carotid artery and $\mathrm{M}_{1}$ portion of middle cerebral artery. Note severe decrease in CoBF during occlusion of middle cerebral artery compared with carotid compression.

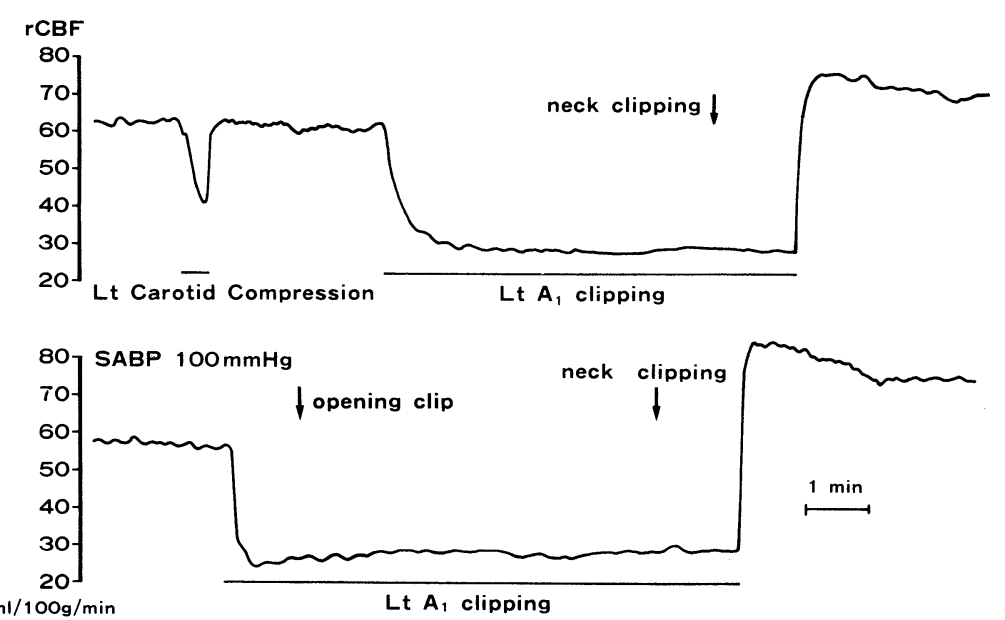

H.T. 73y. F. A Com Aneurysm G III

Fig. 5 Case $5 . \mathrm{CoBF}$ recording during occlusion of $A_{1}$ portion of left anterior cerebral artery. Right $A_{1}$ was hypoplastic. Postoperatively the patient had ischemic infarction in bilateral basal ganglia which corresponded with the territory supplied by perforating branches distal to the occlusion.

断時間は14分であったが，全例虚血症状は出現しなかった.

\section{考案}

Symon らはヒヒを用いて脳主幹動脈閉塞による脳虚血 の $\mathrm{CoBF}$ と神経機能の関係を実験的に検討した結果, $\mathrm{CoBF}$ が50から $20 \mathrm{~m} l / 100 \mathrm{~g} / \mathrm{min}$ 以下になるとシナプス伝導 が障害され， $16 \mathrm{~m} l / 100 \mathrm{~g} / \mathrm{min}$ 以下になると電気活動が著 明に抑制され，10〜 $12 \mathrm{~m} l / 100 \mathrm{~g} / \mathrm{min}$ 以下になると細胞膜 より $\mathrm{K}^{+}$efflux が起こり梗塞が発生することを示した ${ }^{7) ~}$ 194 脳卒中の外科 $16: 1988$
11)
一方, 血流遮断を15分で解除すると, 電気活動は回復し, 1 時間で再開通すると膜のイオン代謝障害は改善すること を報告している7)。 ヒトにおいても，半球脳血流が $30 \mathrm{~m} l / 100 \mathrm{~g} / \mathrm{min}$ 以下になると central conduction time が 延長し ${ }^{12)}, \mathrm{CoBF}$ が $20 \mathrm{~m} l / 100 \mathrm{~g} / \mathrm{min}$ 以下になると皮質電 気活動が消失することが報告されている ${ }^{13)}$.

このように, CoBF のある一定以上の減少は脳電気活動 や細胞膜イオン代謝を障害する結果, 神経機能障害の発現 に直接関与する。脳動脈瘤の手術において, 瘤の剥離や 
premature rupture の際，親動脈の一時血流遮断は手術を 安全確実に行ううえに不可避の操作であるが，先に述べた 理由により，遮断許容時間が常に問題となる.

吉本ら ${ }^{14)}$ はマニトール500 $1000 \mathrm{~m} l$ を前投与すると，後 遺症を発現しない脳主幹動脈の最長遮断時間は, 前大脳動 脈一側 $\mathrm{A}_{1}$ 部 80 分, 両側 $\mathrm{A}_{1}$ 部同時 61 分, 頭蓋内内頸動脈 50 分および中大脳動脈 $\mathrm{M}_{1}$ 部 30 分であると報告した.

Jabre ら ${ }^{15)}$ はマニトール投与しない例の遮断許容時間は, 両側 $\mathrm{A}_{1}$ 部 23 分, 中大脳動脈 40 分, 頭蓋内内頸動脈 27 分, 脳底動脈 13 分であり, 一時遮断を行った群と行わない群 間に後遺症発現に関して有意差はなかったと報告している. 動脈瘤急性期手術でも， $\mathrm{M}_{1}$ 遮断 20 分間は許容できるとい j $^{16)}$.

しかし実際には短時間の血流遮断にもかかわらず，思わ ぬ後遺症をきたす症例を経験することがある．その理由と して, クモ膜下出血によって発生した脳損傷すなわち脳浮 腫, 脳循環代謝障害の程度や側副血行路の発達が個々の症 例で異なることがあげられる. したがって脳主幹動脈一時 血流遮断に際して，その灌流領域の CoBF モニタリング は, 術後神経脱落症状を来さないための重要な指標になる と考えられる。

Carter $ら^{1)}$ は著者の方法と同じヒートクリアランス法を 用いて, 脳動脈瘤術中血流遮断時の CoBF を測定し, 低 血圧のため長時間 $\mathrm{CoBF}$ が $22 \mathrm{~m} l / 100 \mathrm{~g} / \mathrm{min}$ と低下した例で は術後植物状態となったが、 $35 \mathrm{~m} l / 100 \mathrm{~g} / \mathrm{min}$ 程度で短時間 低下した例では後遺症はなかったと報告している.

われわれの結果では, 脳主幹動脈の末梢で遮断するほど, 当然のことながら $\mathrm{CoBF}$ への影響が大きかった. CoBF が $30 \mathrm{~m} l / 100 \mathrm{~g} / \mathrm{min}$ (前值の約 $50 \%$ ) 以上に保たれていた例では, 最高14分間の遮断で問題はなかった。これらの例では遮断 許容時間はもっと長い可能性がある，遮断によって 15 , $25 \mathrm{~m} l / 100 \mathrm{~g} / \mathrm{min}$ に低下した例では遮断時間がそれぞれ 1 , 8 分間であったが, 術後合併症はなかった. しかし, 症例 5 では $30 \mathrm{ml} / 100 \mathrm{~g} / \mathrm{min}$ で $6.5,8$ 分間の 2 回血流遮断を行 ったところ, 術後穿通枝領域の梗塞をきたした. この例の ごとく, 動脈硬化の著明な高齢者においては皮質血流の観 察が必ずしも穿通枝領域の虚血を予測することができない ことを示している.

Jabre $ら^{15)}$ も大脳基底核を栄養する穿通枝を含んだ親動 脈の一時血流遮断の際には時間を短縮するように強調して おり, 5 〜 分間が最長許容時間であろうとしている. CoBF のモニタリングでは穿通枝領域の虚血状態は判定で きないため, 穿通枝中枢側の血流遮断では, 常にその領域 の虚血を念頭において, 遮断時間を極力短縮しなければな らない.

$\mathrm{CoBF}$ 測定のもう 1 つの利点は, 血流遮断に対する
$\mathrm{CoBF}$ の反応から, 遮断後の手術操作の心構えができる点 である. CoBF の低下が大きければ手術を急がねばならず, 低下が少なければ比較的ゆったりと手術を進めることがで きる.いまだ症例数がすくないために血流遮断による $\mathrm{CoBF}$ の低下程度と遮断許容時間の関係については明らか にしえないが, CoBF の術中モニタリングは手術を安全に 行うために有用な方法と考える.

\section{まと め}

脳動脈瘤術中主幹動脈の一時血流遮断に際し, CoBF を 測定した. CoBF の低下程度によって遮断時間を調節した り, 手術操作に対する心構えができる利点がある. 穿通枝 領域の虚血は CoBF 測定では予測できないため, ことに 高歯者においては注意を要することを強調した。

\section{文献}

1) Carter LP, White WL, Atkinson JR: Regional cortical blood flow at craniotomy. Neurosurgery 2: 223-229, 1978

2）早川 徹：熱電対法による術中脳表血流測定一とくにその 臨床的意義について. Neurosurgeons 4:183-190, 1984

3）伊原郁夫, 菊池晴彦: 術中血流測定一プレート型電気分解 式組織血流測定法一. Neurosurgeons 4：201-210, 1984

4) Rosenblum BR, Bonner RF, Oldfield EH: Intraoperative measurement of cortical blood flow adjacent to cerebral AVM using laser Doppler velocimetry. J Neurosurg 66: 396-399, 1987

5) Momma F, Wang AD, Symon L: Effects of temporary arterial occlusion on somatosensory evoked responses in aneurysm surgery. Surg Neurol 27: 343-352, 1987

6) Nornes H, Grip A, Wikeby P: Intraoperative evaluation of cerebral hemodynamics using directional Doppler technique. Part 1: Arteriovenous malformations. J Neurosurg 50: 145-151, 1979

7) Branston NM, Symon L, Crockard HA, et al: Relationship between the cortical evoked potential and local cortical blood flow following acute middle cerebral artery occlusion in the baboon. Exp Neurol 45: 195-208, 1974

8) Branston NM, Symon L, Crockard HA: Recovery of the cortical evoked response following temporary middle cerebral artery occlusion in baboons : Relation to local blood flow and $\mathrm{PO}_{2}$. Stroke 7: 151-157, 1976

9) Astrup J, Symon L, Branston NM, et al: Cortical evoked potential and extracellular $\mathrm{K}^{+}$and $\mathrm{H}^{+}$at critical levels of brain ischemia. Stroke 8: 51-57, 1977

10) Morawetz RB, DeGirolami U, Ojemann RG, et al: Cerebral blood flow determined by hydrogen clearance during middle cerebral artery occlusion in unanesthetized monkeys. Stroke 9: 143-149, 1978

11) Astrup J: Energy-requiring cell functions in the ischemic brain: Their critical supply and possible inhibition in protective therapy. J Neurosurg 56: 482-497, 1982

12) Rosenstein J, Wang A, Symon L, et al: Relationship between hemispheral $\mathrm{CBF}, \mathrm{CCT}$, and clinical grade in aneurysmal subarachnoid hemorrhage. J Neurosurg 62: 25-30, 1985

13) Trojaborg W, Boysen G: Relation between EEG, regional 
cerebral blood flow and internal carotid artery pressure during carotid endarterectomy. Electroencephal Clin Neurophysiol 34: 61-69, 1973

14）吉本高志, 鈴木二郎：常温平常血圧下, 脳動脈瘤の直接手 術: 我々の血流一時遮断延長法を用いて. 脳神経外科 4 : 775-783, 1976
15) Jabre A, Symon L: Temporary vascular occlusion during aneurysm surgery. Surg Neurol 27: 47-63, 1987

16) Ljunggren $B$, Säveland $H$, Brandt $L$, et al: Temporary clipping during early operation for ruptured aneurysm: Preliminary report. Neurosurgery 12: 525-530, 1983 